\section{Interactions between leatherback turtles and killer whales in Namibian waters, including possible predation}

\author{
Simon H. Elwen ${ }^{1 *}$ \& Ruth H. Leeney ${ }^{2}$ \\ ${ }^{1}$ Mammal Research Institute, University of Pretoria, \\ c/o Iziko South African Museum, P.O. Box 61, Cape Town, \\ 8000 South Africa \\ ${ }^{2}$ Muc Mhara Research \& Conservation, Cornwall, U.K. \\ Rceived 3 September 2010. Accepted 19 July 2011
}

Killer whales and leatherback turtles are infrequently sighted in the coastal waters of southern Africa. Year round observations in Walvis Bay, Namibia of killer whales (2003-2010) by multiple marine tour operators and opportunistic seasonal observations of leatherback turtles made during a cetacean research project in the area (2008-2010) have been collated. Visits to coastal waters by killer whales $(n=16)$ are sporadic and unpredictable but are slightly higher $(n=11)$ between late winter (August) and late summer (March). Leatherback turtles were only seen in the warmer periods of summer months (February-March) when the surface waters exceeded $15^{\circ} \mathrm{C}$. Two interactions (one harassment and one probably predation) between killer whales and leatherback turtles have been recorded in Walvis Bay. This is the first report of killer whales eating leatherback turtles in the South Atlantic. These observations are noteworthy due to the low frequency of encounters of both species in the area, suggesting predation of turtles may be relatively common. Knowledge of the diet of killer whales is valuable due to the importance of dietary specialization in definition of ecotypes of the species.

Key words: killer whale, Orcinus orca, leatherback turtle, Dermochelys coriacea, predation, Namibia, Benguela.

\section{INTRODUCTION}

Killer whales (Orcinus orca) are infrequently sighted in the coastal waters of west and southern Africa (Best 2007; Best et al. 2010; Weir et al. 2010). These apparently conform to the more common 'Type A' killer whale (Best 2007; Best

\footnotetext{
*To whom correspondence should be addressed.

E-mail: simon.elwen@gmail.com
}

et al. 2010; Weir et al. 2010) which in Antarctic and sub-Antarctic waters at least, is thought to prey mainly on minke whales (Balaenoptera bonaerensis). Local observations show killer whales in southern African waters to eat a wide range of prey, including whales, dolphins, fur seals, elephant seals, penguins, cormorants and various fish species, with a general bias towards marine mammals (Best 2007).

Records of killer whale predation and knowledge of their diet are valuable in understanding their ecological relationships. Killer whale predation on leatherback and other turtle species has been recorded in the northeastern Pacific and in the Caribbean (Caldwell \& Caldwell 1969; Oviedo et al. 2008) but not previously in the southern African subregion (Best et al. 2010).

Leatherback turtles (Dermochelys coriacea) are listed as critically endangered on the IUCN Red Data List (Sarti Martinez 2000). Most knowledge about leatherback turtles comes from studies of nesting females. Male leatherback turtles leave the beach post-hatching and never return to land, thus limiting opportunities to study these wideranging, deep-diving animals (Lambardi et al. 2008; Sherrill-Mix et al. 2008). Thus areas of known at-sea concentration, where data can be collected on free-ranging adults of both sexes, are potentially highly valuable to the conservation of this species.

Namibia is gaining recognition as a feeding area for leatherback turtles which are thought to be attracted by the large amount of gelatinous plankton in the Benguela ecosystem. (Lynam et al. 2006). These turtles are known to come mainly from Gabonese and Brazilian nesting grounds, based on tag returns from animals found dead in Namibia (R. Braby, pers. comm., Namibia Coast Conservation and Management Project NACOMA, 25 August 2010). In addition, some turtles (two of nine tagged) nesting in the SouthWest Indian Ocean (northeastern South Africa and southern Mozambique) have been tracked into the offshore waters of the highly productive Benguela current ecosystem on the west coast of South Africa and Namibia (Lambardi et al. 2008). In this paper we summarize observations of killer whales and leatherback turtles made in Walvis 
Table 1. Sightings of leatherback turtles (Dermochelys coriacea) in Walvis Bay, Namibia, with associated environmental data. Turtle body (carapace) length was estimated visually for animals approached within $10 \mathrm{~m}$.

\begin{tabular}{|c|c|c|c|c|c|c|}
\hline Date & Time & Number & SST & Depth & $\begin{array}{l}\text { Estimated } \\
\text { size }(m)\end{array}$ & Comment \\
\hline \multicolumn{7}{|l|}{2009} \\
\hline 04 March 2009 & $12: 04$ & 1 & 18.7 & 21.6 & - & \\
\hline 04 March 2009 & $12: 11$ & 2 & 19.4 & 18.7 & - & 1 approached, $1 \sim 100 \mathrm{~m}$ away \\
\hline 12 March 2009 & $10: 18$ & 1 & 22.1 & 27.1 & - & \\
\hline 12 March 2009 & $11: 56$ & 2 & - & - & - & Reported via radio by tour boats \\
\hline 13 March 2009 & 10:03 & 1 & 21.3 & 29 & - & \\
\hline 13 March 2009 & $10: 16$ & 1 & 21.1 & 28.5 & - & \\
\hline 13 March 2009 & 10:20 & 1 & 21.2 & 28 & - & \\
\hline 13 March 2009 & $10: 27$ & 1 & 21.0 & 26.3 & - & \\
\hline 13 March 2009 & $10: 52$ & 1 & 21.1 & 18.9 & - & \\
\hline 17 March 2009 & 8:09 & 1 & 16.2 & 21.9 & 1.3 & \\
\hline 17 March 2009 & $10: 08$ & 1 & & & - & Dead \\
\hline 20 March 2009 & $12: 36$ & 1 & 17.5 & 18 & 1.0 & \\
\hline 21 March 2009 & 8:00 & 1 & 16.8 & 8.4 & & \\
\hline 21 March 2009 & 8:04 & 1 & 17.0 & 9.4 & 0.8 & \\
\hline 21 March 2009 & 13:05 & 1 & 17.3 & 9.3 & 1.0 & \\
\hline \multicolumn{7}{|l|}{2010} \\
\hline 24 February 2010 & $9: 49$ & 1 & - & - & 1.2 & \\
\hline 28 February 2010 & $9: 14$ & 1 & 17.1 & 28.9 & 1.4 & \\
\hline 28 February 2010 & $12: 05$ & 1 & 18.4 & 31.6 & - & \\
\hline 09 March 2010 & 8:12 & 1 & 19.0 & 18.6 & - & $\begin{array}{l}\text { Being harassed by bottlenose } \\
\text { dolphin }\end{array}$ \\
\hline 15 March 2010 & $11: 16$ & 1 & 15.1 & 25.2 & - & Reported via radio by tour boats \\
\hline 19 March 2010 & $10: 49$ & 1 & & & & Closest recorded SST was $15.6^{\circ} \mathrm{C}$ \\
\hline
\end{tabular}

Bay, Namibia and report on the first observation of leatherback turtles possibly being preyed upon by killer whales in southern Africa.

\section{METHODS}

\section{Study area and methods}

Walvis Bay is a large $(\sim 10 \times 10 \mathrm{~km})$ bay, located approximately midway along the Namibian coastline. The bay is formed by a $\sim 10 \mathrm{~km}$ long sand spit along its western edge ending at Pelican Point. A commercial harbour supports pelagic and demersal fishing fleets and a large marine tourism industry, consisting of 27 boats (Elwen \& Leeney 2009). The protected waters and local weather patterns (calm almost every morning), result in glassy flat waters on a regular basis, optimal for spotting turtles and marine mammals. Data were collected in Walvis Bay, Namibia, during 107 dolphin research surveys over two summer and two winter seasons (26, 24, 25, 32 sea days, respectively) between 22 May 2008 and 24 March 2010.

Observations of killer whales were collated from the authors' records, as well as those of the local marine tourism industry from 2003-2010. Although record-keeping is not systematic, unusual sightings such as those of large whales, rare species and predation events are recorded by several companies.

\section{RESULTS}

\section{Turtle sightings in Walvis Bay}

Owing to the number of near-simultaneous sightings reported by tour boats, the speed of the survey vessel and the distance and time between sightings we are confident that within days, the majority of sightings are of different individuals, although between days there may be repeat sightings. Leatherback turtles were only seen during summer seasons and only during the warmer periods 
Table 2. Records of killer whales (Orcinus orca) from Walvis Bay, Namibia, between 2003 and 2009. Reports collated from multiple sources: Francois Visser, Levo Tours (FV), Jeanne Meintjies, Eco-Marine Kayak Tours (JM), Namibian Dolphin Project Records (NDP), Chris Lotz, Birding Ecotours (CL), Orlanda Sardinia, Catamaran Charters (OS), Namib Times Newspaper (NT). No sightings were recorded in 2004 or 2006.

\begin{tabular}{|c|c|c|c|}
\hline Date & Number & Source & Comments \\
\hline 04 August 2003 & $15-20$ & FV & \\
\hline 15 August 2003 & 3 & FV & \\
\hline 12 October 2003 & 2 & $\mathrm{FV}$ & \\
\hline 13 October 2003 & 2 & FV & \\
\hline 28 March 2005 & 5 & FV & 1 male, 2 female, 2 young \\
\hline 31 March 2005 & 6 & FV & 1 male, 3 female, 2 young - 'catching a turtle' \\
\hline 16 November 2005 & 2 & FV & \\
\hline 04 March 2005 & 2 & $\mathrm{CL}$ & 'Offshore' during a pelagic birding trip \\
\hline 14 February 2007 & 7 & FV & \\
\hline 15 January 2008 & $5-15$ & $\mathrm{FV} / \mathrm{JM} / \mathrm{OS} / \mathrm{NT}$ & $\begin{array}{l}\text { FV reports group of } 5 \text {. Namib Times - 'Small } \\
\text { group' eating a turtle, later } 15 \text { animals. }\end{array}$ \\
\hline 26 June 2008 & 2 & NDP/JM/FV & Adults \\
\hline 14 April 2009 & 5 & $\mathrm{JM}$ & West of bay \\
\hline 19 April 2009 & 8 & $\mathrm{JM}$ & Near Swakopmund ( 30 km north) \\
\hline 23 January 2010 & 3 & FV & \\
\hline 29 April 2010 & $?$ & $\mathrm{JM}$ & \\
\hline 01 July 2010 & 5 & FV & \\
\hline
\end{tabular}

within those seasons. Sea-surface temperature (SST) was measured using an on-board Garmin Fish Finder (Table 1). In 2009, 15 sightings (estimated to be 17 turtles, one of which was dead and excluded from the analysis) were made at an average SST of $19.3^{\circ} \mathrm{C}$ (S.D. $=2.11$, range 16.2$22.1^{\circ} \mathrm{C}$ ) which is significantly warmer than the average seasonal SST of $18.2^{\circ} \mathrm{C}$ (S.D. $=2.39$, Student's $t$-test: $P=0.043$ ). In 2010, five turtle sightings were made at an average SST of $17.4^{\circ} \mathrm{C}$ (S.D. $=1.73$, range $15.1-19.0^{\circ} \mathrm{C}$ ), which is significantly warmer than average SST of $16.5^{\circ} \mathrm{C}$ (S.D. $=1.95$; Student's $t$-test: $P=0.234$ ). An unrecorded number of leatherback turtles were reported in the bay by tour boats but not approached closely by the research team and are thus not reflected in the numbers presented here. The bulk of sightings in 2009 occurred over a relatively short period (12-21 May) with several sightings on a single day.

\section{Killer whale sightings in Walvis Bay}

Killer whales have been recorded on 16 occasions since 2003. Sightings are slightly more frequent during late winter (August) to late summer (March). Observed group size ranged from 2-20, with most groups having fewer than seven individuals (Table 2).

\section{Interactions between marine mammals and leatherback turtles}

Two occurrences of turtle-killer whale interactions have been directly observed by marine tour operators in Walvis Bay, Namibia, over the period for which data are available (2003-2010). On 31 March 2005, a turtle was observed to be tossed and flipped several times by a group of killer whales and then bitten on the flank. Blood and entrails were seen (Francois Visser, pers. comm.) before it disappeared, suggesting the animal was at least partially eaten by the killer whales. On 15 January 2008, a group of approximately 15 killer whales was seen to throw a single large leatherback turtle in the air, flip it on its back and drag it underwater (confirmed by S.E., from a video recording by Orlanda Sardinha, Catamaran Charters). The turtle was not obviously bitten and was still alive when the whales departed. Thus we can report here on two clear interactions between killer whales and leatherback turtles with one of those possibly involving a partial predation.

These observations come with the caveat that killer whales are known to play with both prey and non-prey objects at sea (Fertl \& Fulling 2007, Williams et al. 1990), and it may thus be difficult to differentiate true predation from play or harassment only. Conversely, killer whales frequently do 
not eat the whole animal they kill (Jefferson et al. 1991).

\section{DISCUSSION}

Leatherback turtles are frequently observed in the calm waters of Walvis Bay during periods of the summer months when the surface waters exceed approximately $15^{\circ} \mathrm{C}$. They are likely to be more common in the waters of the northern Benguela and further from shore (Lambardi et al. 2008; Omardien 2006) where they face some threat of by-catch from pelagic longliners operating in the region (Omardien 2006). There is no current estimate of the number of killer whales in the African subregion, but the near-constant observer effort provided by the tour boats working in Walvis Bay provides insight into the likely frequency of visits to a given near-shore area. Visits seem to be sporadic and unpredictable both within and between years, although there is some evidence from the sightings records that animals (or groups of animals) may stay in the region for periods of several days. A single pair of killer whales has been recorded to stay around Mercury Island $(\sim 400 \mathrm{~km}$ south of Walvis Bay ) for periods of $4-10$ days during which they harassed and predated on cormorants and Cape fur seals (Williams et al. 1990).

The chance of observing a predation event in the wild is very low, even if they occur frequently (Springer et al. 2008). It is thus of note that of the seven observations of killer whales in the Walvis Bay area made during the warmer summer months (Nov-Mar), predation (or at the very least harassment) of leatherback turtles has been seen twice. The frequency of sightings in Namibia suggests that predation upon leatherbacks may occur regularly during inter-species encounters. Owing to their large body size and feeding frequency, even small groups of killer whales may have an effect on prey populations (Bolt et al. 2009; Williams et al. 1990). Pitman \& Dutton (2004) have suggested that the influence of killer whales should be considered as a factor in the recovery of leatherback turtle populations. To this end, knowledge of the number and diet of killer whales in the southern African subregion would be valuable.

The Namibian Dolphin Project is funded by the Nedbank Go Green Fund, NACOMA (Namibian Coastal Conservation and Management Project), the Mohammed bin Zayed Species Conservation Fund, the British Ecological Society and the Rufford Small Grants Foundation. We are supported in Namibia by the Namibia Nature Foundation.
Many thanks to Jeanne Meintjies, Francois Visser and Orlanda Sardinha for sharing their records. We are indebted to the marine tour operators of Walvis Bay for their support, especially Ingo Venter of Pelican Tours, Catamaran Charters and Mola Mola tours. Thanks to Ryan Reisinger for comments on an earlier draft of this manuscript, J. \& B. Paterson, R. Braby and K. Wearne for support in Walvis Bay. This research was completed under a permit issued to SE \& RHL by the Namibian Ministry of Fisheries \& Marine Resources.

\section{REFERENCES}

BEST, P.B. 2007. Whales \& dolphins of the southern African subregion. Cambridge University Press, Cape Town.

BEST, P.B., MEŸER, M.A. \& LOCKYER, C.. 2010. Killer whales in South African waters - a review of their biology. Afr. J. Mar. Sci. 32: 171-186.

BOLT, H.E., HARVEY, P.V., MANDLEBERG, L. \& FOOTE, A.D. 2009. Occurrence of killer whales in Scottish inshore waters: temporal and spatial patterns relative to the distribution of declining harbour seal populations. Aquat. Conserv. 19: 671675.

CALDWELL, D.K. \& CALDWELL, M.C. 1969. Addition of the leatherback sea turtle to the known prey of the killer whale, Orcinus orca. J. Mamm. 50: 636.

ELWEN, S.H. \& LEENEY, R.H. 2009. The Namibian Dolphin Project: ecology and conservation of coastal dolphins in Namibia. Submitted to The Namibian Ministry of Fisheries and Marine Resources. National Marine Information and Resource Centre, Strand St, Swakopmund. 25 pp.

FERTL, D. \& FULLING, G. 2007. Interactions between marine mammals and turtles. Marine Turtle Newsl. 115.

JEFFERSON, T.A., STACEY, P.J. \& BAIRD, R.W. 1991. A review of killer whale interactions with other marine mammals: predation to co-existence. Mamm. Rev. 21(4): 151-180.

LAMBARDI, P., LUTJEHARMS, J.R.E., MENCACCI, R., HAYS, G.C. \& LUSCHI, P. 2008. Influence of ocean currents on long-distance movement of leatherback sea turtles in the Southwest Indian Ocean. MEPS 353: 289-301.

LYNAM, C.P., GIBBONS, M.J., AXELSON, B.E., SPARKS, C.A.J., COETZEE, J., HEYWOOD, B.G. \& BRIERLEY, A.S. 2006. Jellyfish overtake fish in a heavily fished ecosystem. Curr. Biol. 16: R492R493.

OMARDIEN, A. 2006. Bycatch of threatened seabirds, sharks and turtles in longline fisheries in the Benguela Large Marine Ecosystem: an integrated approach. in A. Omardien (Ed.) BCLME Project (pp. 1-40). WWF Sanlam Marine Programme.

OVIEDO, L., ESTEVES, M.A., ALFE, E., ACEVEDO, R. \& BOLANOS-JIMINEZ, J. 2008. Interaction between killer whales (Orcinus orca) and a leatherback turtle (Dermochelys coriacea) off the north-eastern coast of Venezuela. J. Mar. Biol. Ass. U.K. 2 - Biodiversity Records online.

PITMAN, R.L. \& ENSOR, P. 2003. Three forms of killer 
whales (Orcinus orca) in Antarctic waters. J. Cet. Res. Manag. 5: 131-139.

SARTI MARTINEZ, A.L. 2000. Dermochelys coriacea. In IUCN 2010. IUCN Red List of Threatened Species. 2010.1.

SHERRILL-MIX, S.A., JAMES, M.C. \& MYERS, R.A. 2008. Migration cues and timing in leatherback sea turtles. Behav. Ecol. 19: 231-236.

SPRINGER, A., ESTES, J., VAN VLIET, G., WILLIAMS, T., DOAK, D., DANNER, E., FORNEY, K.A. \& PFISTER B. 2008. Mammal-eating killer whales, industrial whaling, and the sequential megafaunal collapse in the North Pacific Ocean: a reply to critics of Springer et al. 2003. Mar. Mamm. Sci. 24: 414-422.

WEIR, C.R., COLLINS, T., CARVALHO, I. \& ROSENBAUM, H.C.. 2010. Killer whales (Orcinus orca) in Angolan and Gulf of Guinea waters, tropical West Africa. J. Mar. Biol. Ass. U.K. 90: 16011611.

WILLIAMS, A.J., DYER, B.M., RANDALL, R.M. \& KOMEN, J. 1990. Killer whales Orcinus orca and seabirds: "Play", predation and association. Mar. Ornithol. 18: 37-41.

Corresponding Editor: G.I.H. Kerley 